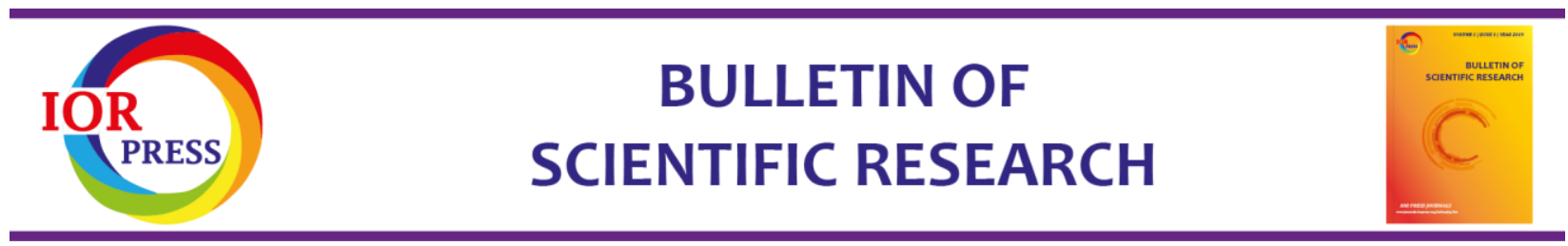

\title{
A Comprehensive Survey on Crack detection of Bone using various techniques
}

\section{S. Agnes Shifani a, *, D. Akshaya a, M. Kaviya a, K. Kiruthiga a,}

a Department of Electronics and Communication Engineering, Jeppiaar Maamallan Engineering College, Chennai, Tamil Nadu, India.

*Corresponding Author: shifaniece2110@gmail.com DOI: https://doi.org/10.34256/bsr2021

Received: 05-04-2020

Accepted: 19-07-2020

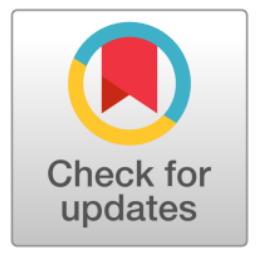

\begin{abstract}
Digital image processing plays a key role in manipulation of image and extracting the maximum amount of data from image with help of various algorithm. Digital image correlation algorithm determines the displacement and deformation of pattern across several images. Creating innovation are developing every day in various fields, particularly in restoration condition. Notwithstanding, still some old strategies are very famous. X-ray or CT images are one among the system for identification of bone cracks. during this article, we offer a comprehensive overview of various algorithm and techniques of displacement measurement generally and crack detection especially using digital image processing. we've been successful in highlighting each and each key feature and aspect of crack detection in bone which can take the add this domain further
\end{abstract}

Keywords: Digital Image Correlation, CT or X-Ray images Digital Image Processing.

\section{Introduction}

Digital image processing is the utilization of the advanced PC to process the advanced handling, pictures through the calculation [1]. As there are numerous subcategories or field upon computerized signal preparing, it has numerous focal points over simple picture handling It permits lot more extensive scope of calculations to be applied to the information and can keep away from issues, for example, the development of clamor and mutilation during preparing [2-5]. The age and advancement of computerized picture handling are primarily influenced by three components: first, the improvement of PCs; further the improvement of arithmetic (particularly the creation and improvement of discrete science hypothesis); and the latter is the interest for a wide scope of uses in condition, farming, military, modern and furthermore in medicinal science has expanded[6,7].

Digital Image Correlation (DIC) is a 3D full-field, non- contact and optical system to quantify and research about shape, distortion, vibration and strain on practically any material[8]. The system can be utilized with numerous tests including malleable, torsion, bowing and consolidated stacking for both static and dynamic applications[9-13]. This technique can be applied from little (miniaturized scale) to (full scale) enormous testing regions - and furthermore the outcomes are promptly practically identical with FEA results or by the strain checks. Advanced Image Correlation will successfully track the development of normally happening, or applied 
surface example during the test or examination [14]. This is finished by examining the relocation of the examples inside discretized subsets or aspect components of the entire picture. The greatest connection in every window compares to the relocation, and this provides the vector length and guidance for every window [15]. With standard single camera or stereoscopic multi camera arrangements, 2D in-plane distortion or full 3D surface estimations are accomplished. Nearby subsidiary counts give the strain tensors over the whole surface, and a standard element of strain ace is the capacity to put a virtual strain check anyplace on the example surface after the test, gives extraordinarily exact strain information.

\section{Literature Survey}

This investigation [16] planned to look at exactness and accuracy mistakes of three Digital Volume Correlation (DVC) approaches in a specific 3D zero-strain condition for both trabecular and cortical bone examples, imaged over and over utilizing miniaturized scale CT. Both scalar normal mistakes and blunders influencing the individual parts of relocations and strains were determined. For each DVC approach, mistakes diminished asymptotically for bigger sub-volume estimates in the range investigated. Thinking about this specific arrangement of pictures, the worldwide methodology (SHIRT-FE) demonstrated a general preferred exactness and accuracy over the neighbourhood ones. The last show sensible outcomes for huge nodal separating, especially for trabecular bone.

This paper [17] offers an outline of the possibilities and constraints of advanced picture connection (DIC) as a strategy for estimating relocations and strain in biomechanical applications. This survey is basically proposed for bio-mechanists who are not yet acquainted with DIC. This survey incorporates more than 150 papers and covers distinctive dimensional scales, from the tiny level (tissue level) up to plainly visible one (organ level). As DIC includes a high level of calculation, and of administrator subordinate choices, dependability of dislodging and strain estimations by methods for DIC can't be underestimated. Methodological issues and existing arrangements are outlined and thought about, while open issues are tended to. Points tended to include: arrangement strategies for the spot design on various tissues; programming settings; orderly and irregular mistake related with DIC estimation. Applications to hard and delicate tissues at various dimensional scales are portrayed and broke down as far as qualities and confinements. The possibilities and impediments of DIC are featured, additionally in examination with other test systems (strain measures, other optical procedures, computerized volume connection) and numerical techniques (limited component investigation), where collaborations and complementarities are talked about. So as to give a diagram available to various researchers working in the field of biomechanics, this paper purposefully doesn't report subtleties of the calculations and codes utilized in the various investigations.

Right now, portrayal of the principle systems and transducers utilized to quantify nearby and worldwide strains instigated by uniaxial stacking of murine tibiae is introduced. Miniaturized scale strain checks and advanced picture connection (DIC) were tried to gauge nearby strains, while a moving loop enginebased length transducer was utilized to quantify relative worldwide shortening. Nearby strain is the urgent parameter to be estimated when managing bone cell mechanotransduction, so we portrayed these systems in the exploratory conditions known to initiate cell mechano-sensing in vivo. The trial tests were performed utilizing tibia tests extracted from twenty-two C57BL/6 mice. To assess estimation repeatability, we processed the standard deviation of ten dull compressions to 
the mean worth. This worth was lower than 3\% for miniaturized scale strain checks, and in the scope of $7 \%-10 \%$ for DIC and the length transducer [18]. The coefficient of variety, i.e., the standard deviation to the mean worth, was about 35\% for strain measures and the length transducer, and about $40 \%$ for DIC. These outcomes gave a far-reaching portrayal of three strategies for neighbourhood and worldwide bone strain estimation, recommending a potential field of use based on their favourable circumstances and impediments.

Human bone is one of the most wellknown connective tissue of natural human structure. Comparable to the inner microstructure there are two principle sorts of bone tissue: minimized in the cortical zone and springy or trabecular in the interior zone. The permeable structure as a rule is side for the marrow. Thinking about the applicable capacity of that tissue, the porosity isn't uniform. Permeable distance across increment from the cortical to the focal point of bones, as the associations of permeable expanding with the thickness of the bone tissue. The nearness of serum inside the permeable structure of bone tissue produce an alternate conduct in bones underneath loads, and related with the state of the heap is applied. The reaction of material is diverse in connection at the degree of serum inside the tissue and in connection of the heap activity heading. In same pressure condition the speed of stacking produce distinctive reaction related with the components of permeable and penetrability parameters. Right now, unique sort of bone tissue was researched.

From Calcaneus, from skull and structure rib of human skeletal framework. The examples are oppressed at pressure test in, dislodging control, until they arrive at a definitive worry, in dry and wet condition. It is seen that degree of serum. A3 gatherings (one for each tissue kind) of 20 examples each are tried in dry and wet condition. most extreme pressure, strain, versatile distortion vitality, complete twisting vitality, are estimated. factual examination is led and subjective relationship are deducted in reference to the thickness and explicit mechanical qualities. The test [19] show conservative tissue as skull are progressively fitting to perform load activity, rather calcaneus function as reticular structure with high twisting levels.

This work [20] expects to appraise the obvious Young's modulus of genuine human trabecular bones utilizing a numerical smaller scale full scale approach. Tube shaped examples of trabecular bone were extricated from human femur heads, cleaned and examined utilizing a SkyScan- 1072 small scale figured tomography framework. 3D volumetric tetrahedral lattices were produced from the abuse of the recreated pictures utilizing unique cross section strategies. Numerical compressive tests were recreated, accepting isotropic tissue Young's mod-ulus for all components. The enormous size of the volumes suggests lattices with a high number of hubs, which required the utilization of countless equal processors so as to play out the limited component computations. Numerical Young's moduli changed between $1300 \mathrm{MPa}$ and 1600 $\mathrm{MPa}$, with a decent concurrence with tests.

\section{Literature Survey Table:}

\begin{tabular}{|c|c|c|c|c|}
\hline REF.NO & PURPOSE & INPUT & METHODOLOGY & OUTCOMES \\
\hline \multirow{2}{*}[1]{} & A novel approach for & X-Ray image & $\bullet$ Pre-processing & Determination of \\
& bone fracture & & $\bullet$ Edge detection & type of \\
& detection using image & & Segmentation & fracture \\
& processing & & Image classifier & \\
\hline
\end{tabular}




\begin{tabular}{|c|c|c|c|c|}
\hline [2] & $\begin{array}{c}\text { A review on strain } \\
\text { measurement in bone } \\
\text { mechanics using various } \\
\text { techniques }\end{array}$ & $\begin{array}{l}\text { Digital image (cortical } \\
\text { bone) } \\
\text { Computed tomography }\end{array}$ & $\begin{array}{ll}\text { - } & \text { Strain methodology } \\
\text { - } & \text { Digital } \\
& \text { volume/Image } \\
& \text { correlation } \\
\text { - } & \text { Fiber Bragg grating } \\
& \text { sensors }\end{array}$ & $\begin{array}{l}\text { Measurement of noise } \\
\text { effect Identification of } \\
\text { inner stress }\end{array}$ \\
\hline [3] & $\begin{array}{c}\text { A scheme of } \\
\text { deformation } \\
\text { measurement for } \\
\text { cancellous bones } \\
\text { based on DIC } \\
\text { methods }\end{array}$ & $\begin{array}{l}\text { Porcine femur - } \\
\text { specimen } \\
\text { (A type of cortical } \\
\text { bone) }\end{array}$ & $\begin{array}{ll}- & \text { Preparation of } \\
\text { specimen } \\
\text { - } & \text { Indentation test on } \\
\text { cancellous bone }\end{array}$ & $\begin{array}{c}\text { Measurement of small } \\
\text { deformations (Porous } \\
\text { material) }\end{array}$ \\
\hline [4] & $\begin{array}{l}\text { A model-based } \\
\text { approach to investigate } \\
\text { The effect of a long } \\
\text { bone fracture on } \\
\text { ultrasonic strain } \\
\text { electrography }\end{array}$ & $\begin{array}{c}\text { Intact and } \\
\text { fractured rabbit } \\
\text { femur samples }\end{array}$ & 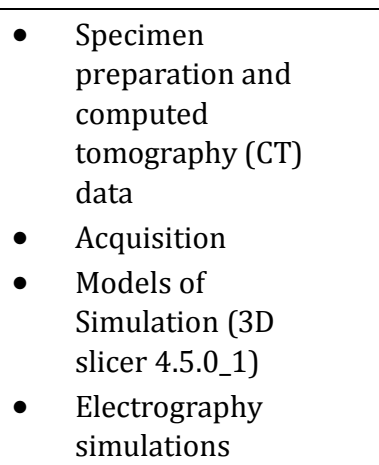 & $\begin{array}{c}\text { Differentiation of } \\
\text { fractured femurs from } \\
\text { the intact one Detection } \\
\text { of fractures in long bone }\end{array}$ \\
\hline [5] & $\begin{array}{l}\text { Bone fracture detection } \\
\text { system using image } \\
\text { processing and } \\
\text { MATLAB }\end{array}$ & $\begin{array}{c}\text { CT/MRI } \\
\text { X-ray image }\end{array}$ & $\begin{array}{ll}\text { - } & \text { Image enhancement } \\
\text { - } & \text { Image segmentation } \\
\text { - } & \text { Feature extraction } \\
\text { - } & \text { Image Classification }\end{array}$ & $\begin{array}{c}\text { Automatic detection of } \\
\text { crack in a leg bone } \\
\text { Recognition of bone } \\
\text { split }\end{array}$ \\
\hline [6] & $\begin{array}{l}\text { Automatic detection of } \\
\text { fracture in femur bone } \\
\text { using image processing }\end{array}$ & $\begin{array}{c}\text { Foreground } \\
\text { (suppress the } \\
\text { background details of } \\
\text { image) } \\
\text { X-Ray }\end{array}$ & $\begin{array}{ll}- & \text { Preprocessing } \\
- & \text { Edge detection } \\
\text { - } & \text { Support vector } \\
& \text { Machine(SVM) }\end{array}$ & $\begin{array}{l}\text { Classify and visualize } \\
\text { the deformities in } \\
\text { femur bone }\end{array}$ \\
\hline [7] & $\begin{array}{l}\text { Advanced bone crack } \\
\text { detection using image } \\
\text { processing techniques }\end{array}$ & $\begin{array}{l}\text { X-ray beam } \\
\text { CT image }\end{array}$ & $\begin{array}{ll}\text { - } & \text { Image fusion (CT and } \\
& \text { DWT) } \\
\text { - } & \text { Edge detection } \\
\text { - } & \text { Complex wavelet } \\
& \text { transform }\end{array}$ & $\begin{array}{l}\text { Efficient and Precise } \\
\text { crack characterization } \\
\text { of bone crack }\end{array}$ \\
\hline [8] & $\begin{array}{l}\text { Crack detection in x-ray } \\
\text { images using fuzzy } \\
\text { index measure }\end{array}$ & $\begin{array}{l}\text { Different image } \\
\text { acquisition } \\
\text { parameter (x-ray } \\
\text { image) }\end{array}$ & $\begin{array}{ll}\text { - } & \text { Adaptive threshold } \\
\text { algorithm } \\
\text { - } & \text { Region splitting } \\
\text { - } & \text { Image subtraction } \\
\text { - } & \text { Morphological } \\
& \text { filtering }\end{array}$ & $\begin{array}{l}\text { Improve the accuracy of } \\
\text { crack detection by } \\
\text { increasing the error }\end{array}$ \\
\hline [9] & $\begin{array}{c}\text { Long bone fracture } \\
\text { detection using artificial } \\
\text { neural networks based } \\
\text { on contour features of } \\
\text { X- ray images }\end{array}$ & X-Ray images & $\begin{array}{ll}\text { - } & \text { Contour Histogram } \\
\text { feature based fracture } \\
\text { detection (CHFB) }\end{array}$ & $\begin{array}{c}\text { To obtain high accuracy } \\
\text { with reduced number of } \\
\text { data through detected } \\
\text { contour }\end{array}$ \\
\hline$[10]$ & $\begin{array}{l}\text { Crack Detection of } \\
\text { medical bone image } \\
\text { using contrast } \\
\text { Stretching Algorithm } \\
\text { with help of edge } \\
\text { detection }\end{array}$ & X-Ray image & $\begin{array}{ll}\text { - } & \text { Histogram } \\
& \text { Equalization } \\
\text { - } & \text { Contrast stretching } \\
& \text { algorithm } \\
\text { - } & \text { Edge detection }\end{array}$ & $\begin{array}{l}\text { To find out the accuracy } \\
\text { of x-ray detection of } \\
\text { crack bone }\end{array}$ \\
\hline
\end{tabular}




\begin{tabular}{|c|c|c|c|c|}
\hline [11] & $\begin{array}{c}\text { Quantitative analysis } \\
\text { and fracture detection } \\
\text { of pelvic bone X-Ray } \\
\text { images }\end{array}$ & $\begin{array}{l}\text { X-Ray images MRI } \\
\text { image }\end{array}$ & $\begin{array}{ll}- & \text { Gray level co- } \\
\text { occurrence matrix } \\
\text { (GLCM) } \\
\text { - } & \text { Edge Detection } \\
\text { - } & \text { Segmentation }\end{array}$ & $\begin{array}{c}\text { Automatic Detection of } \\
\text { Major and Minor } \\
\text { Fracture Accurately }\end{array}$ \\
\hline [12] & $\begin{array}{c}\text { Digital image } \\
\text { correlation techniques } \\
\text { for strain measurement } \\
\text { in a variety of } \\
\text { biomechanical test } \\
\text { models }\end{array}$ & $\begin{array}{l}\text { Aluminium alloy } \\
\text { Polyurethane } \\
\text { foam specimen } \\
\text { Laminated } \\
\text { polyurethane } \\
\text { foam } \\
\text { specimen } \\
\end{array}$ & $\begin{array}{ll}\text { - } & \text { Compression } \\
\text { - } & \text { Bending test } \\
\text { - } & \text { Digital image } \\
& \text { correlation }\end{array}$ & $\begin{array}{l}\text { To measure Strain in } \\
\text { Bone and bone } \\
\text { substitutes }\end{array}$ \\
\hline [13] & $\begin{array}{c}\text { Bone Fracture } \\
\text { Detection from X-Ray } \\
\text { image of human fingers } \\
\text { using image processing }\end{array}$ & $\begin{array}{c}\text { Electronic } \\
\text { radiation, X-Ray } \\
\text { image }\end{array}$ & $\begin{array}{ll}\text { - } & \text { Edge Detection } \\
\text { - } & \text { Segmentation } \\
\text { - } & \text { ROI Detection } \\
\end{array}$ & $\begin{array}{l}\text { Bone fracture detection } \\
\text { from X-Ray of human } \\
\text { finger }\end{array}$ \\
\hline [14] & $\begin{array}{l}\text { Intelligent bone } \\
\text { fracture Detection } \\
\text { system }\end{array}$ & $\begin{array}{l}\text { X-Ray image of } \\
\text { different bone } \\
\text { fracture }\end{array}$ & $\begin{array}{ll}\text { - } & \text { Haar Wavelet } \\
\text { Transform } \\
\text { - } & \text { Scale-Invariant } \\
& \text { Feature Transform } \\
& \text { (SIFT) algorithm } \\
\end{array}$ & $\begin{array}{c}\text { Detection and } \\
\text { classification of bone } \\
\text { fracture }\end{array}$ \\
\hline [15] & $\begin{array}{l}\text { Detection of Vertebral } \\
\text { Body Fractures based } \\
\text { on Cortical Shell } \\
\text { Unwrapping }\end{array}$ & X-ray images & $\begin{array}{ll}\text { - } & \text { Spinal column } \\
\text { segmentation and } \\
\text { portioning }\end{array}$ & $\begin{array}{l}\text { To detect vertebral } \\
\text { fracture on trauma }\end{array}$ \\
\hline
\end{tabular}

\section{Conclusion}

In this paper, a comprehensive survey on crack detection of bone using various techniques is completed. The digital image processing systems are exceptionally useful for examining the deformities of grouped surfaces by applying different techniques like Edge detection, image segmentation, image feature extraction, image enhancement, fiber Bragg grating sensors, image classification, strain methodology, digital image correlation Every different technique has its own benefits and negative marks. From this audit, it alright could also be comprehended that a couple of techniques gives more accurate result and error rate is additionally reduced.

\section{References}

[1] A. M. Tripathi, A. Upadhyay, A. S. Rajput, A. P. Singh, B. Kumar, (2017) Automatic detection of fracture in femur bones using image processing. In 2017 International Conference on Innovations in Information, Embedded and Communication Systems (ICIIECS), IEEE, 1-5. 
[2] D.B. Bhakare, P. A. Jawalekar, S. D. Korde, Novel Approach for Bone Fracture Detection Using Image Processing, International Research Journal of Engineering and Technology (IRJET), 5 (2018) 193-195.

[3] B Harinath, Sitrarasu, T.J. Nagalakshmi, Bone Fracture Detection System using Image Processing and Matlab, International Journal of Innovative Technology and Exploring Engineering, 8 (2019) 1459- 1461.

[4] G. Ramyapriyanandhini. Advanced Bone Crack Detection Using Image Processing Techniques, International Journal of Innovative Research in Electrical, Electronics, Instrumentation and Control Engineering, 5 (2017) 80-83.

[5] C. H. Linda, G. W. Jiji, Crack Detection in X-Ray Images Using Fuzzy Index Measure, Applied Soft Computing, 11(2011) 3571-3579.

[6] S. Tang, E. P. Sabonghy, A. Chaudhry, P. S. Shajudeen, M. T. Islam, N. Kim, R. Righetti, (2018) A Model-Based Approach to Investigate the Effect of a Long Bone Fracture on Ultrasound Strain Elastography, IEEE Transactions on Medical Imaging, 37 (12) 2704-2717.

[7] H. Xiong, S. Li, T. Xiao, (2015) A Scheme of Deformation Measurement for Cancellous Bones Based on The Digital Image Correlation Method, In 2015 8th International Conference on Biomedical Engineering and Informatics (BMEI), IEEE, 391-396.

[8] S. A. Shifani, V. Nanammal, R. Bhavani, A. A. Nishidha, (2017) A Review on Strain Measurement in Bone Mechanics Using Various Techniques, In 2017 IEEE International Conference on Computational Intelligence and Computing Research (ICCIC), IEEE, 1-5.

[9] S. Hensley, M. Christensen, S. Small, D. Archer, E. Lakes, R. Rogge, Digital Image Correlation Techniques for Strain Measurement in A Variety of Biomechanical Test Models, Acta of bioengineering and biomechanics, 19 (2017) 1-9.

[10] A. K. Bharodiya, A. M. Gonsai, (2019) Bone fracture detection from X-ray image of human fingers using image processing. In Emerging Trends in Expert Applications and Security, Springer, Singapore, 47-53.

[11] J. Yao, J. E. Burns, H. Munoz, R. M. Summers, (2012) Detection of Vertebral Body Fractures Based on Cortical Shell Unwrapping, In International Conference on Medical Image Computing and Computer-Assisted Intervention, Springer, Berlin, Heidelberg, 509-516.

[12] S. Yelne, R. Tomar, A. Jadhao, R. Boriwar, Crack Detection of Medical Bone Image Using Contrast Stretching Algorithm with The Help of Edge Detection, International Journal of Scientific Engineering and Technology, 4 (2015) 223-227.

[13] R. Vijayakumar, G. Gireesh, (2013) Quantitative Analysis and Fracture Detection of Pelvic Bone X-Ray Images, In 2013 Fourth International Conference on Computing, Communications and Networking Technologies (ICCCNT), IEEE, 1-7.

[14] K. Dimililer, IBFDS: Intelligent Bone Fracture Detection System, Procedia computer science, 120 (2017) 260-267.

[15] A. Y. Yang, L. Cheng, M. Shimaponda-Nawa, H. Y. Zhu, (2019) Long-Bone Fracture Detection using Artificial Neural Networks based on Line Features of X-ray Images, In 2019 IEEE Symposium Series on Computational Intelligence (SSCI), IEEE, 2595-2602.

[16] G. Tozzi, M. Palanca, L. Cristofolini, M. Viceconti, E. Dall'Ara, 3D Local Measurements of Bone Strain and Displacement: Comparison of Three Digital Volume Correlation Approaches, Journal of Biomechanical Engineering, 137 (2015) 1-14.

[17] M. Palanca, G. Tozzi, L. Cristofolini, The Use of Digital Image Correlation in The Biomechanical Area: A Review, International biomechanics, 3 (2016) 1-21. 
[18] E. Rizzuto, B. Peruzzi, M. Giudice, E. Urciuoli, E. Pittella, E. Piuzzi, Z. Del Prete, (2019) Detection of the Strains Induced in Murine Tibias by Ex Vivo Uniaxial Loading with Different Sensors, Sensors, 19 (23) 1-19.

[19] M. Cammarata, F. Nicoletti, M. D. Paola, A. Valenza, G. Zummo, (2016) Mechanical Behaviour of Human Bones with Different Saturation Levels, Conference, 2nd International Electronic Conference on Materials, MDPI, 1-12.

[20] K. Madi, G. Aufort, A. Gasser, S. Forest, (2010) Prediction of The Elastic Modulus of The Trabecular Bone Based on X-Ray Computed Tomography, In 6th World Congress of Biomechanics (WCB 2010), Springer, Berlin, Heidelberg, 800-803.

Acknowledgement: NIL

Funding: NIL

Conflict of Interest: NIL

About the License: (C) 2020 The Authors. This work is licensed under a Creative Commons Attribution 4.0 International License which permits unrestricted use, provided the original author and source are credited. 